From the Department of Obstetrics and Gynaecology and Department of Animal Breeding and Genetics, Swedish University of Agricultural Sciences, Uppsala, Sweden.

\title{
Differential Cell Counting in Fraction-Collected Milk from Dairy Cows
}

\author{
By Karin Östensson, Matts Hageltorn and Göran Åström
}

\begin{abstract}
Östensson K, M. Hageltorn and G. Åström: Differential cell counting in fractioncollected milk from dairy cows. Acta vet. scand. 1988, 29, 493-500. - Cell concentrations and cell populations were studied in fraction-collected milk by use of cytofluorometric methods. The results indicate differences in the condition of udders producing milk with more and less than 100000 cells per ml, respectively.
\end{abstract}

flow cytometry.

\section{Introduction}

The total cell concentration in the milk is the most frequently used measurement in the diagnosis of subclinical mastitis. In normal milk from cows during full lactation the cell content consists of practically only white blood cells among which the monocyte macrophage population dominates. A small percentage of the cells in milk are epithelial cells (Lee et al. 1980).

The cell concentration in milk taken from one cow at one particular occasion varies depending on the fraction of the milk analysed (Paape \& Tucker 1966, se also Schalm et al. 1971). So far very little is known about the variation in cell populations (lymphocytes, granulocytes, monocytes and macrophages) in different milk fractions.

Recent advances in flow cytometry technology have expanded the use of these techniques into a variety of fields including differential analysis of cells in milk (Hageltorn \& Saad 1986) after staining with metachromatic and supravital dye acridine orange. This technique has been applied in the present study. The four fractions analysed are the foremilk (Fraction I), the quarter bulk milk (Fraction II), the strippings milk (Fraction III) and the residual milk (Fraction IV). The aim of the present work was to study the variations of cell concentration and cell populations in milk fractions I-IV and to relate these variations to the health status of the udder.

\section{Material and methods}

Five dairy cows, Swedish Red and White breed, in full lactation, 2 to 3 years of age without clinical symptoms of mastitis and bacteriologically negative were included in this investigation. The cows were milked daily at 7.30 a.m. and 3 p.m. From 4 of the cows, milk samples were collected on 2 occassions with a 1 month interval and from 1 cow the milk was taken on just 1 occasion. The milk samples were taken during the morning milking. Total cell concentration of the quarter bulk milk from the 36 quarter milkings varied from 25000 to 570000 per $\mathrm{ml}$. Less than 300000 cells per $\mathrm{ml}$ were found in the milk from 33 out of the total 36 quarter bulk milk samples examined. In the 
present investigation each quarter was considered as one unit on each sampling occasion.

Each milk sample had a volume of $50 \mathrm{ml}$. The first $10 \mathrm{ml}$ milked from each quarter were discarded. The next $50 \mathrm{ml}$, obtained by hand milking, were called fraction I. Fraction II was taken directly after fraction I by using a quarter milking machine from the collecting cylinders of which the samples were taken after careful stirring. After removal of the quarter milking machine, the quarters were handstripped to collect fraction III and emptied. Finally, 10 IU of oxytocin were injected into the jugular vein and after 1 min fraction IV was collected by hand milking.

\section{Staining technique of milk}

The milk samples were diluted 1:200 in a hypotonic phosphate buffered saline $(\mathrm{pH}$ 7.4) to which $4 \mathrm{mg} / \mathrm{l}$ acridine orange was added (Adams \& Kamentsky 1974) prior to flow cytofluorometric analysis.

\section{Flow cytometry}

A Cytofluorograph 50L (Ortho Diagnostic Instruments, Westwood, Mass., USA) equipped with a $100 \mathrm{~mW}$ argon ion laser was used. The excitation wave length was 488 $\mathrm{nm}$ and the output power was adjusted to 20 $\mathrm{mW}$. Dual parameters were registered by the measuring of green fluorescence at 515-575 $\mathrm{nm}$ and red fluorescence at $600-650 \mathrm{~nm}$. The pulse area values were used throughout the measurements. The amplitudes of the cellular red and green fluorescence were determined from the $\mathrm{X}$ and $\mathrm{Y}$ position on the cathode ray tube, respectively. Dead cells and debris were excluded by proper discriminator settings. The selecting window no 1 was gating the lymphocyte cluster and selecting window no 2 the neutrophil and lymphocyte clusters. The percentage of re- gistered cells within the two selecting windows in relation to the total registered events were digitally displayed. The monocyte macrophage population was calculated by subtracting the number of lymphocytes and granulocytes from the total count. Finally $0.4 \mathrm{ml}$ of the diluted samples were counted by the flow cytometer for calculating the absolute number of living cells per ml milk.

\section{Statistical methods}

The milk samples were divided into two groups according to the total cell concentration in the quarter bulk milk samples. Group 1 with a cell concentration $<100000$ per ml and group 2 with a cell concentration between 100000 and 570000 per $\mathrm{ml}$. The groups consisted of samples from 19 and 17 quarter milkings respectively.

All data were treated by analyses of variance. Data were analysed with Statistical Analysis System (SAS institute Inc. 1986) using the General Linear Models procedure. The analyses were performed according to the following model:

$$
\text { Yijk }=\mu+q i+f j+(g f) i j+e_{i j k}
$$

Yijk $=$ the ijkth observation

$\mu \quad=$ general mean

gi $=$ effect of the ith group $(i=1,2)$

fj $=$ effect of the jth fraction $(j=1,2,3,4)$

(gf)ij = interaction between the ith group and the jth fraction

$\mathrm{e}_{\mathrm{ijk}} \quad=$ residual random term

\section{Results}

Means for total cell content, lymphocytes, granulocytes and monocyte-macrophages are shown in Table 1. The total cell concentration in group 1 averaged 89, 64, 117 and $152 \times 10^{3}$ per $\mathrm{ml}$ in the first, second, third and fourth fraction respectively. In group 2 the corresponding figures were 197, 


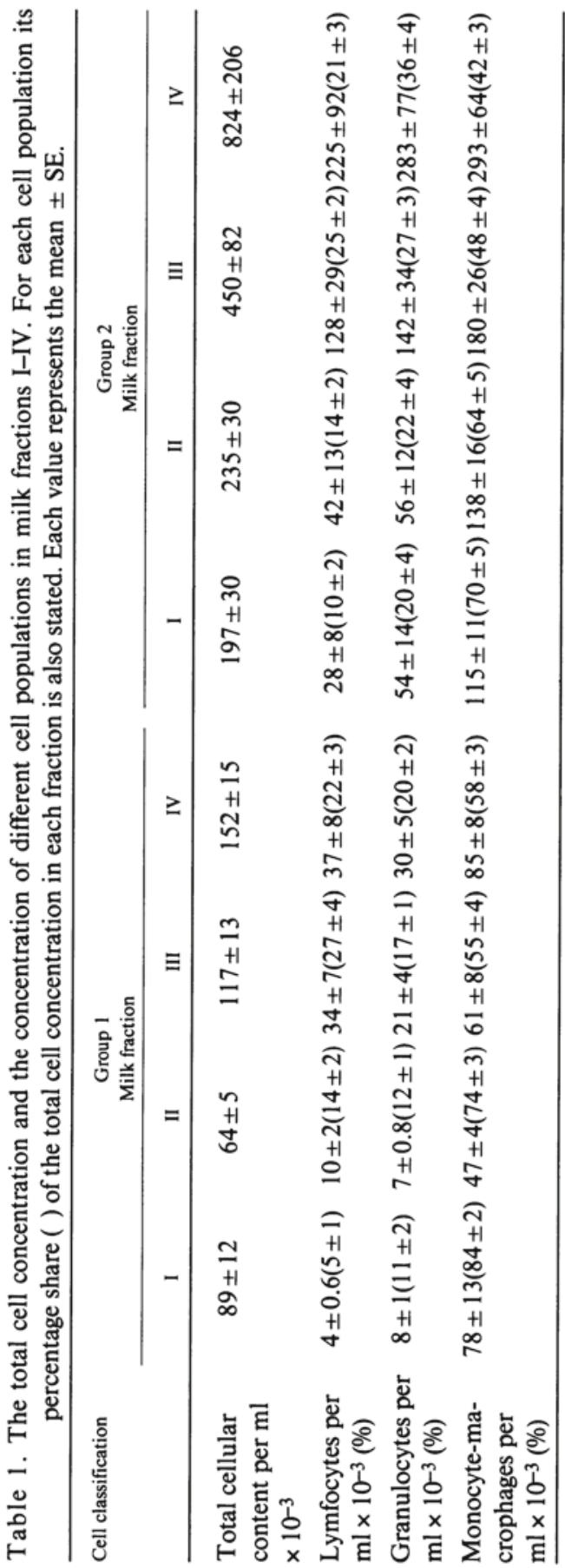

235,450 and $824 \times 10^{3} \mathrm{per} \mathrm{ml}$. The increase in the total cell concentration between fraction I and fraction IV in group 1 was $71 \%$ (Table 2). The corresponding figure for group 2 was $318 \%$. The difference between the total cell concentration in fraction I and fraction IV in group 2 was highly significant $(\mathrm{p}<0.001)$ (Table 5).

Numerically there was an increase in all types of cells from fractions I and II to fractions III and IV in both groups. However, the increase of the monocyte-macrophage types of cells in group 1 appears to be slight (Table 1).

The numerical increase of phagocytes (granulocytes and monocyte-macrophages) represented about $48 \%$ of the increase of the total cell concentration from fraction I to fraction IV in group 1 (Table 2). On the other hand in group 2 the numerical increase of phagocytes from fraction I to fraction IV formed the major part ( $69 \%)$ of the increase of the total cell concentration.

Concerning the proportions of the different cell populations this study gave the following results. An increase in the percentage of lymphocytes of the total cell content was seen in fractions III and IV as compared to

Table 2. The increase in total cell concentration and in the concentration of different cell populations from milk fraction I to milk fraction IV. For each cell population its percentage share (\%) of the increase in total cell concentration is also stated. The given figures are calculated from the means.

\begin{tabular}{lrrr}
\hline Cell classification & \multicolumn{2}{c}{$\begin{array}{c}\text { Increase in cell number } \\
\text { per ml } \times 10^{-3} \\
\text { from fraction 1-IV }\end{array}$} \\
\cline { 2 - 4 } & Group 1 & Group 2 \\
\hline Total cell concentration (\%) & $63(71)$ & $627(318)$ \\
Lymfocytes (\%) & $33(52)$ & 197 & $(31)$ \\
Granulocytes (\%) & $22(36)$ & 252 & $(40)$ \\
Monocyte-macrophages (\%) & $7(12)$ & 179 & $(29)$ \\
\hline
\end{tabular}


Table 3. Differences between fractions within groups regarding the percentage share of respective cell population of the total cell concentration, and degree of significance.

\begin{tabular}{|c|c|c|c|}
\hline Cell classification & Milk fraction & \multicolumn{2}{|c|}{ Degree of significance } \\
\hline Lymfocytes & $\begin{array}{c}\text { I-II } \\
\text { I-III } \\
\text { I-IV } \\
\text { II-III } \\
\text { II-IV } \\
\text { III-IV }\end{array}$ & $\begin{array}{c}\mathrm{P}<0.05 \\
\mathrm{P}<0.001 \\
\mathrm{P}<0.001 \\
\mathrm{P}<0.001 \\
\mathrm{P}<0.05 \\
\quad \text { N.S. }\end{array}$ & $\begin{array}{c}\text { N.S. } \\
\mathrm{P}<0.001 \\
\mathrm{P}<0.01 \\
\mathrm{P}<0.01 \\
\mathrm{P}<0.05 \\
\quad \text { N.S. }\end{array}$ \\
\hline Granulocytes & $\begin{array}{c}\text { I-II } \\
\text { I-III } \\
\text { I-IV } \\
\text { II-III } \\
\text { II-IV } \\
\text { III-IV }\end{array}$ & $\begin{array}{c}\text { N.S. } \\
\text { N.S. } \\
\mathrm{P}<0.05 \\
\text { N.S. } \\
\mathrm{P}<0.05 \\
\text { N.S. }\end{array}$ & $\begin{array}{c}\text { N.S. } \\
\text { N.S. } \\
\mathrm{P}<0.001 \\
\text { N.S. } \\
\mathrm{P}<0.001 \\
\mathrm{P}<0.05\end{array}$ \\
\hline Monocyte-macrophages & $\begin{array}{c}\text { I-II } \\
\text { I-III } \\
\text { I-IV } \\
\text { II-III } \\
\text { II-IV } \\
\text { III-IV }\end{array}$ & $\begin{array}{l}\mathrm{P}<0.05 \\
\mathrm{P}<0.001 \\
\mathrm{P}<0.001 \\
\mathrm{P}<0.001 \\
\mathrm{P}<0.01 \\
\quad \text { N.S. }\end{array}$ & $\begin{aligned} & \text { N.S. } \\
\mathrm{P} & <0.001 \\
\mathrm{P} & <0.001 \\
\mathrm{P} & <0.01 \\
\mathrm{P} & <0.001 \\
& \text { N.S. }\end{aligned}$ \\
\hline
\end{tabular}

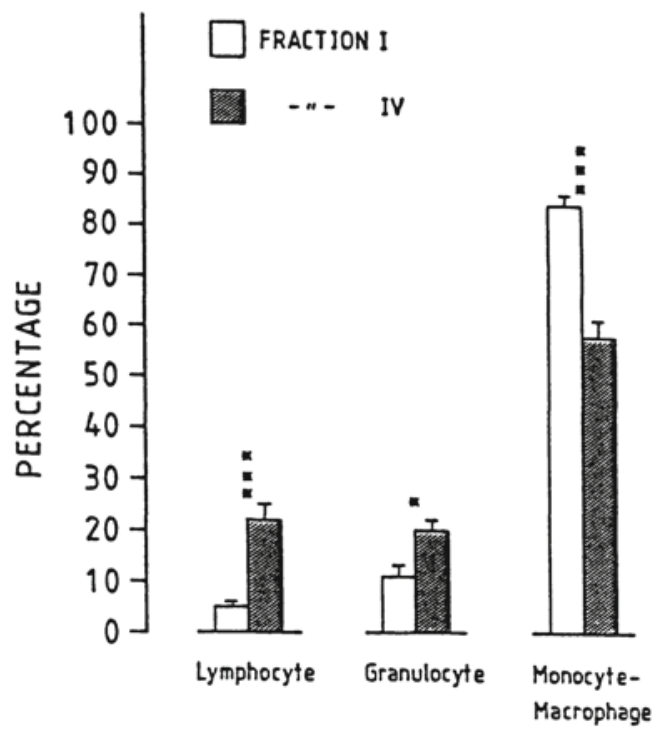

Figure 1. Proportions of respective cell population in fraction I and IV in group 1. The given figures are means.

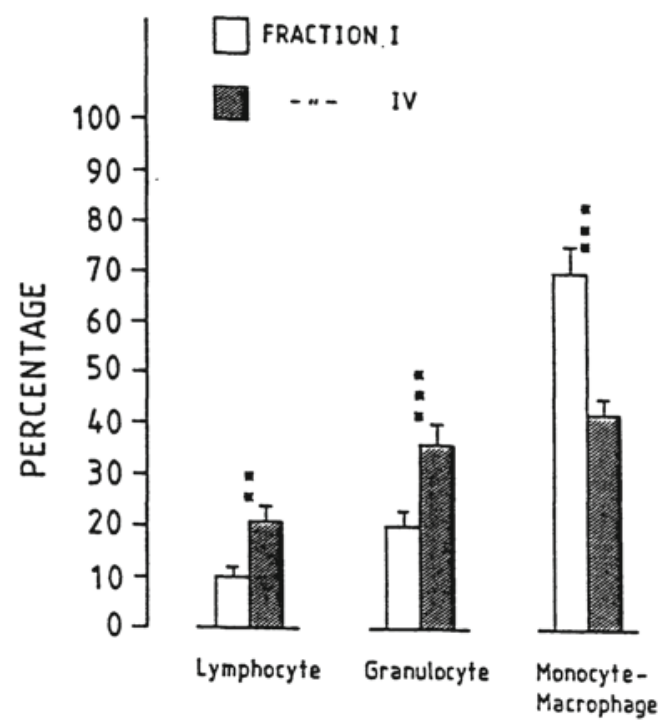

Figure 2. Proportions of respective cell population in fraction I and IV in group 2. The given figures are means. 
fractions I and II in group 1 (Table 1). A tendency towards a corresponding increase in group 2 was also seen. The percentage of granulocytes increased also from fractions I and II to fractions III and IV in both groups. The percentage of monocyte-macrophages on the other hand showed a $20-30 \%$ decrease from fractions I and II to fractions III and IV in group 1 as well as in group 2. Statistically significant differences in both groups are found between fractions I and IV with respect to the percentage share of respective cellpopulation of the total cell concentration (Table 3, Fig. 1 and 2). The corresponding differences between fraction II and IV in both groups were also statistically significant.

Comparing the same fraction number in the two groups, a statistically significant difference is found between fractions I in groups 1 and 2 , and fractions IV in groups 1 and 2 regarding the percentage share of granulo- cytes and monocyte-macrophages respectively. The corresponding differences regarding lymfocytes are not statistically significant (Table 4).

Regarding the numerical values of the lymfocyte content and the content of granulocytes and monocyte-macrophages respectively fraction IV in group 2 is highly significantly different from fraction I and II $(p<0.001)$ and significantly different from fraction III (regarding lymfocytes $\mathrm{p}<0.05$, regarding granulocytes and monocyte-macrophages $\mathrm{p}<0.01$ ) within the group (Table $5)$. In group 1 there are no statistically significant differences between any fractions with respect to the number of cells within respective cell population.

Comparing the same fraction number in the two groups with regard to the numerical values of the total cell content and the content of lymfocytes and granulocytes respectively, a significant difference in the present

Table 4. Differences between the same fraction number in the two groups regarding the total cell count, the cell content of the different cell populations and their percentage share of the total cell concentration ( ) and degree of significance.

\begin{tabular}{lccc}
\hline & Milk fraction & \multicolumn{2}{c}{ Degree of significance } \\
\hline Total cell content & I-I & N.S. & $(-)$ \\
& II-II & N.S. & $(-)$ \\
& III-III & P $<0.01$ & $(-)$ \\
Lymfocytes & IV-IV & P $<0.001$ & $(-)$ \\
& I-I & N.S. & $($ N.S. $)$ \\
& II-II & N.S. & (N.S.) \\
Granulocytes & III-III & P $<0.05$ & (N.S.) \\
& IV-IV & P $<0.001$ & $($ N.S. $)$ \\
& I-I & N.S. & $(\mathrm{P}<0.05)$ \\
& II-II & N.S. & $(\mathrm{P}<0.01)$ \\
Monocyte-macrophages & III-III & P $<0.01$ & $(\mathrm{P}<0.05)$ \\
& IV-IV & $\mathrm{P}<0.001$ & $(\mathrm{P}<0.001)$ \\
& I-I & N.S. & $(\mathrm{P}<0.01)$ \\
& II-II & $\mathrm{P}<0.05$ & $(\mathrm{~N} . S)$. \\
& III-III & $\mathrm{P}<0.001$ & $(\mathrm{~N} . S)$. \\
& IV-IV & $\mathrm{P}<0.001$ & $(\mathrm{P}<0.01)$ \\
\hline
\end{tabular}


Table 5. Differences between fractions within group 2 regarding the total cell content and the different cell populations, and degree of significance.

\begin{tabular}{llll}
\hline & Milk fraction & $\begin{array}{c}\text { Degree of } \\
\text { significance }\end{array}$ \\
\hline Group 2 & & & \\
Total cell content & I & III & $\mathrm{P}<0.01$ \\
& I & IV & $\mathrm{P}<0.001$ \\
& II & IV & $\mathrm{P}<0.001$ \\
Lymfocytes & III & IV & $\mathrm{P}<0.001$ \\
& I & III & $\mathrm{P}<0.05$ \\
& I & IV & $\mathrm{P}<0.001$ \\
Granulocytes & II & IV & $\mathrm{P}<0.001$ \\
& III & IV & $\mathrm{P}<0.05$ \\
& I & III & $\mathrm{P}<0.05$ \\
& I & IV & $\mathrm{P}<0.001$ \\
& II & III & $\mathrm{P}<0.05$ \\
& II & IV & $\mathrm{P}<0.001$ \\
Monocyte-macrophages & III & IV & $\mathrm{P}<0.01$ \\
& I & IV & $\mathrm{P}<0.001$ \\
& II & IV & $\mathrm{P}<0.001$ \\
& III & IV & $\mathrm{P}<0.01$ \\
\hline
\end{tabular}

material was found between groups 1 and 2 in fraction III (Table 4). The corresponding difference regarding the content of monocyte-macrophages in fractions III was highly significant. Comparing fractions IV in the two groups the present material shows a highly significant difference between groups 1 and 2 regarding both the total cell count as well as the content of lymfocytes, granulocytes and monocyte-macrophages respectively.

When the cow was included as one source of variation in the statistical analyses all the significant differences commented on above were still significant.

\section{Discussion}

In the present study the milk samples containing $<100000$ somatic cells per ml were assumed to have emanated from healthy ud- der quarters. Earlier investigations of milk from healthy udders during full lactation have shown that the cell concentration lies below 100000 per ml (Holm 1934, Plastridge et al. 1939, Malcolm et al. 1942, 1944, Chu 1949, Mac Farlane et al. 1949, Mac Leod \& Andersson 1952, Pontrel \& Rainard 1982 and Brolund 1985). Milk samples containing > 100000 somatic cells per $\mathrm{ml}$ were assumed to have emanated from subclinically inflammated quarters. However, in this work the condition of the udders was not confirmed by histopathological investigations. The range of total cell concentrations from 25000 to 570000 per $\mathrm{ml}$ was thought to be of interest, as difficulties in diagnosis of subclinical mastitis arises within this range.

It is known that the cell concentration varies among fractions of milk. Thus Papee \& Tucker (1966) showed that the cell concentration in the foremilk is lower than in the strippings milk. This agrees with the present results. However, the increase from fraction I to fraction IV in the present work differed between the two groups. The rise in cell concentration in group 2 was tenfold higher $(627000$ versus 63000$)$ than in group 1 (Table 2). This result most probably indicates a difference between the conditions of the udders in the two groups. Group 2 showed a larger percentage of granulocytes in the total number of cells in the four milk fractions than group 1 (Table 1) which also indicates differences between the groups. The milk in group 2 probably emanates from udders with more inflammatory foci than the milk in group 1. This is further emphasized by the proportionally higher increase of the total phagocytes (granulocytes and monocyte-macrophages) from fraction I to fraction IV in the milk of group 2 as compared to the milk in group 1. One might speculate that milk ejection from inflammed parts of 
the udder quarter does not function normally. Probably the higher concentrations of inflammatory cells in fractions III and IV reflects a lesser dilution of the milk ejected from this inflammatory foci, in the milk from the rest of the quarter.

Comparing the same fraction number in the two groups, with respect to the total cell count and the content of lymfocytes, granulocytes and monocyte-macrophages respectively, there is a highly significant difference only between fractions IV in group 1 and in group 2 (Table 4). The data might indicate that fraction IV reflects more relevantly the inflammatory condition in the udder tissue than the other fractions.

It is suggested that for research purpose it may be adequate to analyse 2 milk samples, for instance foremilk and residual milk, in order to get a more precise characterization of the condition of the udder.

\section{Acknowledgements}

This study was supported by grants from the Swedish University of Agricultural Sciences and from the Swedish Council for Forestry and Agricultural Research.

\section{References}

Adams LR, Kamentsky LA: Fluorometric characterization of six classes of human leukocytes. Acta Cytologica 1974, 18, 389-391.

Brolund $L$ : Cell counts in bovine milk, causes of variation and applicability for diagnosis of subclinical mastitis. Acta vet. scand. 1985, suppl. 80.

Chu SJ: Bovine Mastitis: A comparison of the value of diagnostic methods. J. comp. Path. Ther. 1949, 59, 81-90.

Hageltorn M, Saad AM: Flow cytometric characterization of bovine blood and milk leukocytes. Amer. J. vet. Res. 1986, 47, 2012-2016.

Holm GC: The types of leucocytes in market milk as related to bovine mastitis. J. Amer. vet. med. Ass. 1934, 35, 735-746.

Lee CS, Wooding FBP, Kemp P: Identification, properties and differential counts of cell populations using electron microscopy of dry cows secretions, colostrum and milk from normal cows. J. Dairy Res. 1980, 47, 39-50.

McFarlane D, Blackburn PS, Malcolm JF, Wilson $A L$ : A comparison of antemortem and postmortem findings in bovine mastitis. Vet. Rec. 1949, 61, 807-810.

MacLeod P, Anderson EC: A study of the cell counts of milk from healthy cows. Bull Storrs agric. Exp. Stn. 1952, 290, 1-23.

Malcolm JF, King CW, Campbell MM: The value of the cell content and electrical conductivity of milk as criteria of bovine mastitis. Proc. Soc. agric. Bact. 1942, 30-34.

Malcolm JF, King CW, Campbell MM: The features of early mastitis in heifers during the first lactation. Vet. Rec. 1944, 56, 227-230.

Paape MJ, Tucker HA: Somatic cell content variation in fraction-collected milk. J. Dairy Sci. 1966, 49, 265.

Plastridge $W N$, Anderson EO, Williams $L F$, Weirether FJ: Infectious bovine mastitis: 7 . Characteristics of udder staphylococci. Bull. Storrs agric. Exp. Stn. 1939, 231, 1-60.

Pontrel B, Rainard P: Predicting the probability of quarter infection (by major pathogens) from somatic cell concentration. Amer. J. vet. Res. 1982, 43, 1296-1299.

Schalm OW, Carroll EJ, Jain NC: Bovine mastitis. Lea \& Febiger, Philadelphia 1971.

\section{Sammanfattning \\ Differentialräkning av celler $i$ olika \\ mjölkfraktioner från ko.}

Cellkoncentrationer och cellpopulationer (lymfocyter, granulocyter och monocyter-makrofager) studerades i fyra mjölkfraktioner (I, II, III och IV) från juverfjärdedelar vars huvudmjölkfraktion, fraktion II, innehöll $<100000$ celler per ml (grupp 1) resp. $\geq 100000$ celler per ml (grupp 2). Flödescytometriska metoder användes för att identifiera och räkna cellerna.

Ökningen av cellkoncentrationen mellan fraktion I och fraktion IV i grupp 1 var $71 \%$, från $89 \times 10^{3}$ till $152 \times 10^{3}$ celler per ml. Motsvarande ökning i grupp 2 var $318 \%$, från $197 \times 10^{3}$ till $824 \times 10^{3}$ celler per $\mathrm{ml}$. 
Ökningen av lymfocyterna och fagocyterna representerade ca $50 \%$ vardera av den totala ökningen från fraktion I till fraktion IV i grupp 1. I grupp 2 var motsvarande ökning av fagocyterna och lymfocyterna $69 \%$ respektive $31 \%$. Då respektive cellpopulations storlek i de olika fraktionerna jämförs inom respektive grupp så är fraktion IV statistiskt signifikant skiljd från fraktion I endast $\mathrm{i}$ grupp 2. Vid en motsvarande jämförelse mellan respektive cellpopulations procentuella andel av den totala cellhalten i respektive fraktion finns det däremot en skillnad mellan fraktion I och IV inom både grupp 1 och 2 .

Vid en jämförelse mellan de två grupperna, av re- spektive cellpopulations storlek i samma fraktionsnummer så är fraktionerna IV i grupp 1 och 2 statistiskt signifikant skiljda från varandra. Då motsvarande jämförelse görs avseende respektive cellpopulations procentuella andel av den totala cellhalten i respektive fraktion så föreligger en statistiskt säkerställd skillnad mellan fraktionerna IV i grupp 1 och 2 endast avseende granulocyter respektive monocyter-makrofager.

Resultaten tyder på att skillnader föreligger mellan juverfjärdedelarna $\mathrm{i}$ de båda grupperna. Sannolikt kommer mjölken i grupp 2 från fjärdedelar med flera inflammatoriska härdar än mjölken i grupp 1 .

(Received May 20, 1988).

Reprints may be requested from: Karin Östensson, Dept. of Obstetrics and Gyneacology, P. O. Box 7039, Swedish University of Agricultural Sciences, S-750 07 Uppsala, Sweden. 